\title{
Возможно ли в России неоиндустриальное импортозамещение?
}

\begin{abstract}
С.А. ЖИРОНКИН, доктор экономических наук. E-mail: zhironkin@inbox.ru М.A. ГАСАНОВ, доктор экономических наук. E-mail: maq@tpu.ru К.А. колотОВ, Национальный исследовательский Томский политехнический университет, Томск. E-mail: 594950@bk.ru
\end{abstract}

В статье обоснована необходимость выхода российской экономики на путь неоиндустриального развития, драйвером которого должно стать импортозамещение. Рассмотрена его типология и показана роль государства в обеспечении выхода из институциональных ловушек неоиндустриального импортозамещения. На примере анализа проблемы импортозависимости базовых отраслей промышленного региона (Кемеровская область) даны рекомендации по развитию машиностроения как отрасли, импортозамещение в которой способно ускорить воссоздание конкурентоспособного обрабатывающего сектора экономики на новой технологической основе, с опорой на потенциал добывающего комплекса. Ключевые слова: неоиндустриализация, деиндустриализация, импортозависимость, импортозамещение, машиностроение, Кузбасс

Сегодня в экономике развитых стран идут структурные трансформации, связанные с развертыванием ультрасовременной технологической базы промышленности. «Новая индустриализация» в США, Великобритании, Германии, Франции, Японии приняла форму подготовки самых высокотехнологичных звеньев глобальных производственных цепочек к грядущей цифровизации, экспансии нейронных сетей, NBIC-конвергенции. В результате технологии 3D-печати, «Интернета вещей», облачных вычислений, биохимии и биомеханики активно проникают в базовые отрасли - машиностроение и приборостроение, энергетику, строительство, химию полимеров и топлива. Все это говорит о переходе лидирующих стран к тренду импортозамещения - возрождению базовых отраслей национальной промышленности на новой технологической основе, предпосылки которого заметны, например, в США, ранее экспортировавших продукцию обрабатывающих производств («программа Д. Трампа») [Грозовский, 2017], а также странах, планирующих создание их на базе сырьевого сектора ${ }^{1}$.

\footnotetext{
${ }^{1}$ Видение Саудовской Аравии. Официальный сайт «Сауди Пресс Эйдженси». URL: http://www.spa.gov.sa/galupload/ads/vision-2030-ru.pdf (дата обращения: 01.03.2017).
} 
На этом фоне экономика России обнаружила неспособность восстановить ту технологическую идентичность, которая досталась ей в наследство от СССР. Результатом рыночных реформ стала деиндустриализация - «сжатие» промышленности и сокращение удельного веса обрабатывающего сектора. Критический уровень (более $50 \%$ ) импорта продукции четвертого и пятого технологических укладов (радиоэлектроника, химия полимеров, приборо-, автомобиле-, самолетостроение, фармацевтика, программирование и пр.) создает барьер для выхода на траекторию стабильного экономического роста. Поэтому любые попытки инициировать импортозамещение в отраслях промышленности, где технологические цепочки длиннее, чем в сельском хозяйстве, в котором в 2014-2016 гг. наблюдался «бум» отечественного производства, обречены на неудачу.

\section{Импортозамещение: автаркия или неоиндустриализация?}

Какое влияние деиндустриализация российской экономики оказывает на рост ее импортозависимости? Сопоставим динамику этих процессов за два последних десятилетия.

Технологическая примитивизация российской промышленности лишила значительную ее часть не только международной, но и внутренней конкурентоспособности. В частности, за 1994-2014 гг. доля отраслей пятого технологического уклада в России сократилась с $20 \%$ до $10 \%$ ВВП (в США - выросла с $50 \%$ до 60\%), четвертого (машиностроение, приборостроение, органическая химия и пр.) - с 60 до 50\%, шестого - не превысила 0,5\% (в США достигла 6\%). При этом доля третьего технологического уклада (добывающие отрасли, металлургия, строительство мегаполисов, доминировавшие в передовых странах во второй половине XIX в.) в России выросла с 20 до 30\% от ВВП, в СШАсоставила менее $10 \%$ (расчет авторов по данным Федеральной службы государственной статистики $)^{2}$.

Негативные структурные сдвиги в инновационно-технологической сфере отбросили Россию на позиции СССР 1950-х гг. К началу 2010 г. на долю России приходилось лишь 2,2\% новых

2 Федеральная служба государственной статистики. Раздел «Программа международных сопоставлений». URL: http://www.gks.ru/wps/wcm/connect/rosstat_main/rosstat/ ru/statistics/icstatistics/program_of_comparisons/ (дата обращения: 01.03.2017). мировых исследований, а в инновационную деятельность были вовлечены только 6\% научных организаций (в США - 75\%). Менее $1 \%$ крупных российских компаний занимаются НИОКР (в США-65\%). В результате конкурентоспособность российской экономики на мировом рынке с 1998 г. снизилась к 2010 г. в четыре раза, а выпуск отраслей шестого технологического уклада в 2012 г. составил 1,5 млрд долл. (в Южной Корее, например, 350 млрд долл.) [Глазьев, 2012. С. 5].

При этом за 1998-2015 гг. импортозависимость российской экономики выросла с 7,1\% до 14,9\%. Доля импорта в станкостроении достигла $60 \%$, в тяжелом машиностроении $-45 \%$, в легкой промышленности $-40 \%$, в радиоэлектронике $-58 \%$, в фармацевтической и медицинской отраслях $-65 \%$. Зависимость от ввоза транспортных средств выросла с 11,8 до 42,9\% (расчеты авторов по данным Федеральной службы государственной статистики ${ }^{3}$ ). А в целом на нужды промышленности приходится $84 \%$ материального импорта. Рост импортозависимости наблюдается не только в обрабатывающих, но и в добывающих отраслях (за 2000-2014 гг. - с 4,0 до 6,9\%).

Из-за неинновационного развития российской экономики «цепь импортозависимости» берет начало в выпуске средств производства в базовых отраслях (четвертый технологический уклад), которые зависят от импорта в среднем на $60 \%$, отрасли пятого уклада - на 70\%, шестого - на все $100 \%$.

Импортозависимость фиксируется не только в реальном секторе - с 2014 г. невозможность импорта капитала с международного финансового рынка лишает Россию 40 млрд долл. ежегодно (до 16\% от совокупных инвестиций в основной капитал), альтернативы которым национальный рынок капитала предоставить не может.

Зарубежные исследования показали, что протекционизм без стимулирования инновационного развития промышленности ведет к долгосрочному снижению национальной конкурентоспособности и росту импортозависимости, тогда как повышение производительности в базовых экспортоориентированных отраслях за счёт импортозамещения позволяет сформировать тренд

${ }^{3}$ Федеральная служба государственной статистики. Раздел «Национальные счета». URL: http://www.gks.ru/wps/wcm/connect/rosstat_main/rosstat/ru/statistics/accounts/ (дата обращения: 01.03.2017). 
самоподдерживающегося роста [Пребиш, 1992. С. 88]. А переход к экспорту продукции обрабатывающих отраслей невозможен без инновационного развития производств для внутреннего рынка. Эти теории нашли подтверждение в процессе промышленного развития Аргентины в 1970-1980-х гг., Южной Кореи 1990-х и Китая 2000-х гг., где рост государственно-частных инвестиций в образование и инновации способствовал смене технологических укладов и спилловер-эффекту - переходу от роста внутренней конкурентоспособности к международной [Линдерт, 1992. С. 62].

Таким образом, импортозамещение следует трактовать как ключ к восстановлению на новой технологической основе обрабатывающих отраслей, ориентированных на внутренний рынок. Однако цепная форма импортозависимости российской экономики, недостаточно развитые институты и неблагоприятный макроэкономический фон делают конечный результат этого процесса инвариантным - от автаркического до неоиндустриального.

Автаркическое импортозамещение, реализованное в СССР, означает отказ от интеграции в глобальные технологические цепочки и попытку частично воссоздать их внутри страны, отстранение от участия в международном движении капитала и трансфере инноваций.

Низкая эффективность такой модели подтверждается невыполнением пятилетних планов в послевоенный период. С начала десятой пятилетки (1976-1980 гг.) наметились старение материальной базы промышленности и технологическое отставание в электронике и наукоёмком производстве от ведущих стран мира, рост военных расходов и теневой сферы народного хозяйства. Все это привело к росту импортозависимости российской экономики к началу реформ. Следовательно, автаркическое импортозамещение не может выступать целью структурных преобразований.

Догоняющее импортозамещение - результат строительства в России с конца 1990-х гг. сборочных предприятий крупнейших мировых автомобилестроительных, радиоэлектронных, химических, пищевых корпораций. Несмотря на то, что к концу 2000 -х гг. эти отрасли обеспечивали до $40 \%$ внутреннего спроса на промышленную продукцию, технологическое отставание всего обрабатывающего комплекса, равно как и зависимость государственных финансов от добычи и экспорта сырья, только усилились. В результате российская промышленность стала полностью зависимой от импорта современного оборудования.

Неоиндустриальное импортозамещение - развертывание в экономике России элементов глобальных цепочек производства в процессе технологической модернизации обрабатывающих отраслей, ориентированных на внутренний рынок. Приоритетной сферой должен стать выпуск средств производства, востребованных базовыми отраслями российской промышленности.

Для восстановления обрабатывающей промышленности на новой технологической основе и насыщения внутреннего рынка требуются, с одной стороны, импорт технологий, с другой - значительные инвестиции. Однако замедление роста прямых инвестиций в 2013 г. (88\% от уровня 2010 г.), международные санкции и экономическая рецессия 2015 г. (с сокращением ВВП на 3,7\%) привели к 30-кратному спаду прямых иностранных инвестиций (3,6 млрд долл. в 2014 г. против 116,2 млрд долл. в 2010 г., по данным ФСГС). Для неоиндустриального импортозамещения необходимо технологическое сотрудничество российских и зарубежных компаний. Сохранение накопленного в России потенциала прикладной науки и его применение требуют вертикальной интеграции производителей ресурсов, промежуточных и готового продуктов, организаций НИОКР, финансовых компаний и банков.

С этой целью неоиндустриальное импортозамещение должно быть опосредовано развитием новых видов экономических связей:

- b2b (business-to-business): создание технологической платформы и сетевого кластера импортозамещения, объединяющих разные формы взаимодействий университетов, НИИ и КБ, предприятий-заказчиков НИОКР и инновационные кластеры на кроссплатформенной и межкластерной основе;

- в2g (business-to-government): формирование государственно-частного партнерства неоиндустриального импортозамещения, которое в перспективе может быть трансформировано в импортозамещающие холдинги с государственным участием:

- b2s (business-to-society): инновационное развитие обрабатывающего сектора в рамках «четвертичной спирали», в которой реализуется запрос на инновации и конкурентоспособные отечественные блага со стороны гражданского общества.

\section{Неоиндустриальное импортозамещение: как выйти из институциональных ловушек}

Импортозамещение, даже неоиндустриальное, несет в себе определенные риски (коррупция и отток иностранных инвестиций, дефицит на потребительских рынках и ухудшение социального благополучия, рост бюджетных расходов). Для их 
минимизации необходимо развитие институциональной базы. Однако процесс импортозамещения в российской промышленности изначально попал в институциональные ловушки, поэтому попытки инициировать его административными методами (господдержка, прямые субсидии, запретительные пошлины, эмбарго) не принесли ожидаемого эффекта.

Институциональные ловушки представляют собой устойчивые деструктивные нормы и правила, которые со временем не только не ослабевают, но и укрепляются и взаимоиндуцируются [Полтерович, 1998. С. 12], поскольку являются результатом устранения государства из процесса экономического стимулирования модернизации и инновационного развития промышленности в условиях незрелого рынка средств производства и инвестиций. Эти ловушки можно охарактеризовать следующим образом.

1. Низкая экономическая эффективность государственных инвестиций и недостаточный технологический уровень госкомпаний, которые не стали лидерами инновационного развития. Продолжающаяся национализация российской экономики не ведет к росту ее конкурентоспособности и замещению импорта.

2. Консервация низкого уровня развития институтов рынка (прав собственности, правил обмена, норм управления) в рентно-сырьевой модели экономики препятствует эффективному стимулированию спроса на отечественные средства производства и инновационные ноу-хау со стороны промышленности, в которой технологически связанные инвестиции невыгодны, а запросы со стороны бизнес-сообщества на улучшение рыночных институтов не формируются.

3. Вызывает опасения неконтролируемый структурный сдвиг, который может произойти при сокращении доли сырьевого сектора в ВВП без опережающего инновационного развития современных обрабатывающих производств.

4. В российской экономике НИОКР в обрабатывающих отраслях в значительной степени сконцентрированы именно в оборонно-промышленном комплексе. Но его превращение в драйвер неоиндустриального импортозамещения затрудняют высокие удельные издержки мелкосерийного производства продукции «двойного применения»,

Эти ловушки тесно переплетены с технологическими проблемами импортозамещения. Следовательно, выход из них требует комплексных институциональных изменений, стимулирующих спрос на отечественные средства производства со стороны российской промышленности, воссоздания в ней разорванных воспроизводственных связей, формирования новых взаимодействий государства и бизнеса, восстановления крупных отраслевых субъектов как центров инновационного развития обрабатывающего сектора. Поэтому комплекс институциональных мер, поддерживающих становление неоиндустриального импортозамещения в российской экономике, должен включать в себя следующее.
А. Смену институционального режима (порядок принятия и применения норм, принуждения к их выполнению, лоббирования экономических интересов определенными группами) с силового на инновационный, соответствующий запросам бизнес-сообщества. При этом реализованы могут быть только институциональные изменения, осуществимые в сложившихся условиях. Радикальные институциональные новации должны сопровождаться последовательным внедрением новых норм, импортом и трансплантацией эффективных институтов из-за рубежа, поиском консенсуса сырьевого и обрабатывающего бизнеса при корректировке промышленной политики.

Следовательно, государство необходимо рассматривать как инициатора импортозамещающих структурных преобразований, но ведущая роль в них должна отводиться конкурирующим компаниям. Поэтому механизм смены институционального режима должен включать разработку и принятие законов, гарантирующих максимальные налоговые льготы и защищающих права интеллектуальной собственности для опережающего импорта технологий; совместное с бизнесом обсуждение развития институтов конкурентной среды и стимулирования спроса на отечественные средства производства; формирование государственно-частных партнерств в инновационной сфере, обеспечивающих спрос на инновации со стороны промышленности и предложение инвестиций; корпоративный образовательный заказ на подготовку промышленного персонала с передовыми компетенциями.

Б. Выход на институциональную траекторию неоиндустриального развития с заменой неэффективных институтов. Для этого необходим импорт эффективных «промежуточных» институтов, учитывающих как российские реалии, так и конечную цель (нормы и правила, стимулирующие конкурентоспособные производства для внутреннего рынка). К ним относятся положительно зарекомендовавшие себя в США целевые программы привлечения инвестиций в модернизацию базовых отраслей, создание министерства технологического развития и инноваций (Япония), налоговое стимулирование контрактных связей между инновационными и промышленными кластерами (США и Франция), усиление защиты интеллектуальной собственности путем выделения особых общедоступных технологий (Германия, Япония) 
В. Создание благоприятной институциональной среды («конечных» целевых институтов). Для этого должны быть приняты государственные стратегические программы, предусматривающие:

- совместное привлечение средств госкорпораций и частных инвесторов в обрабатывающие производства;

- неоиндустриальное импортозамещение - развертывание в ближайшие 2-3 года в российской экономике фрагментов глобальных производственных цепочек (промышленные комплектующие, радиоэлектронные компоненты, программное обеспечение);

- передачу технологий от зарубежных компаний российским в рамках прямых иностранных инвестиций.

Важнейшим элементом институциональной среды должен стать инвестиционно-технологический альянс государства и бизнеса.

\section{Импортозамещение для Кузбасса: неоиндустриализация или ожидание декарбонизации?}

В последнее десятилетие Кузбасс - крупнейший угольный бассейн России, продолжает наращивать объемы добычи ископаемого топлива. За 1996-2016 гг. объемы угледобычи выросли с 96 млн т до рекордных 227 млн т, превысив дореформенный «потолок» в 153 млн т. Восьмикратный рост за период 2005-2015 гг. продемонстрировал выпуск кокса (с 13,6 до 102,3 млрд руб.). В 2,5 раза увеличились объемы выпуска химической продукции (частично экспортируемой), в 1,15 раза - производства электроэнергии (поставляемой, кроме Кузбасса, в другие регионы) ${ }^{4}$. При этом мировые цены на уголь, в особенности энергетических марок, составляющих наибольшую долю кузбасской угледобычи, достаточно нестабильны. Так, цена FOB в российском порту «Восточный» колебалась от 110 долл./т в 2008 г. до 52 долл./т в конце 2016 г. и более 75 долл./т в середине 2017 г.

Закрепление моносырьевой специализации крупнейшего в России угледобывающего региона несет в себе значительные социально-экономические риски. Так, с конца 2000-х гг., когда го-

${ }^{4}$ Данные Территориального органа Федеральной службы государственной статистики по Кемеровской области. Раздел «Валовый региональный продукт». URL: http://kemerovostat.gks.ru/wps/wcm/connect/rosstat_ts/kemerovostat/ru/statistics/grp/ довые объемы угледобычи в Кузбассе приблизились к 200 млн т, 11-14\% добытого угля не находило покупателей, накапливаясь на складах предприятий. А постепенное «торможение» (с 6,9\% до 3,8\% за последние пять лет) экономики Китая и стран ЮгоВосточной Азии грозит снижением спроса на уголь в ближайшие 5-10 лет на 14-15\%. Между тем экономика Кемеровской области крайне чувствительна к колебанию выручки от угольного экспорта, достигающего $35 \%$ от общего объема угледобычи.

Наконец, курс ведущих стран на декарбонизацию, провозглашенный в 2015 г. лидерами стран «Большой семерки», предполагает повышение энергоэффективности строительных проектов, быстрый рост альтернативной энергетики, улавливание и использование углеродных отходов, биотоплива и водорода. В результате к 2045 г. потребление ископаемых видов топлива в мире может сократиться на 35\% [Сакс, 2015].

В этом свете уже не кажутся столь утопичными идеи о превращении Сибири в безуглеродную зону, поскольку объективный процесс снижения энергоемкости промышленных объектов, городов и транспорта в грядущее десятилетие может привести к сокращению потребления угля не только в мире, но и в России [Сидорович, 2017].

Свою лепту в сокращение внутреннего спроса на твердое ископаемое топливо вносит и рецессия, ежегодно уменьшающая внутренний спрос на уголь на $1,5-2 \%$.

Фактически локальная «декарбонизация» уже затронула многие угольные города Кузбасса, в которых к 2017 г. практически не осталось угольных шахт - по причине усложнения горно-геологических условий и исчерпания легко разрабатываемых «дешевых» запасов [Жернов, 2017. С. 16]. Так, в «столице» сибирской угледобычи - Прокопьевске - ни осталось ни одной полноценной шахты, тогда как еще двадцать лет назад их насчитывалось шестнадцать. Аналогичная ситуация сложилась в старейшем центре угледобычи - Анжеро-Судженске. В результате социально-экономическая обстановка в этих городах, в которых еще 25 лет назад функционировали крупнейшие машино- и приборостроительные предприятия («Прокопьевский завод шахтной автоматики», «Анжеромаш»), существенно осложнилась [Голофастова и др., 2017. С. 68].

На этом фоне тренды выпуска машиностроения, приборостроения и сырья для их производства (металлургия) в Кузбассе 
демонстрируют гораздо менее уверенную позитивную динамику (рост в 1,2 и 1,1 раза за 2005-2015 гг.), нежели угольная отрасль.

Такой разрыв в темпах добычи сырья и его первичной переработки, с одной стороны, и обрабатывающих производств (прежде всего, выпуск средств производства - машино-, приборостроения) - с другой, вызван деградацией в регионе комплекса инновационно-ориентированных отраслей. Так, массовые банкротства привели к сокращению количества приборо- и машиностроительных предприятий региона со 116 до 37. Численность занятых в сфере научного обслуживания региональной индустрии упала с 18 тыс. чел. до 1,6 тыс. Количество НИИ и КБ уменьшилось с 19 до семи, а число патентов, регистрируемых в Кемеровской области, сократилось за 1995-2015 гг. с 487 до 127.

Результатом деиндустриализации в экономике Кемеровской области стало углубление проблемы импортозависимости, что иллюстрирует сравнительная динамика добычи и экспорта угля, металлов, с одной стороны, и импорта машиностроительной продукции - с другой. По данным текущего архива Администрации Кемеровской области, устойчивый рост угледобычи в регионе (на 109\% за 1998-2015 гг.) сопровождался ускоренной заменой средств производства на угольных шахтах и разрезов. Однако при этом в Кузбассе наблюдался опережающий рост импорта продукции машиностроения (в четыре раза за 2002-2012 гг.). В 2014 г. виток девальвации привел к падению объема регионального машиностроительного импорта (с 1360 до 322 млн долл.), однако уже в 2015 г. он вырос на 8\%. Структура импортозависимости угольной отрасли Кузбасса отражена в таблице.

Данные таблицы свидетельствуют о том, что техническая и технологическая модернизация угольной отрасли более чем наполовину обеспечивается импортным оборудованием, и до $60 \%$ отдельных видов горношахтного оборудования импортируется из «санкционных» стран - США, ЕС, Австралии; на угольных разрезах 90\% нового оборудования - импортное. Это обусловливает падение объемов выручки кузбасского машиностроения более чем на $25 \%$ - с 56,3 млрд руб. в 2011 г. до 35,0 млрд руб. в 2015 г., на фоне колебаний объемов его инвестирования с 927,6 млн руб. в 2009 г. до 1535,7 млн руб. и 1032,2 млн руб. в 2015 г. В результате региональный машиностроительный комплекс не имеет стимулов к возрождению.
Отдельные показатели импортозависимости угольной отрасли Кузбасса в 2015 г.

\begin{tabular}{|l|c|c|c|c|}
\hline \multirow{2}{*}{ Наименование оборудования } & \multicolumn{2}{|c|}{ Отечественное } & \multicolumn{2}{|c|}{ Импортное } \\
\cline { 2 - 5 } & $\begin{array}{c}\text { Количество } \\
\text { (ед.) / балансо- } \\
\text { вая стоимость, } \\
\text { млрд руб. }\end{array}$ & $\begin{array}{c}\text { Доля } \\
\text { в общем } \\
\text { количест- } \\
\text { ве, \% }\end{array}$ & $\begin{array}{c}\text { Количество } \\
\text { (ед.) / ба- } \\
\text { лансовая } \\
\text { стоимость }\end{array}$ & $\begin{array}{c}\text { Доля } \\
\text { в общем } \\
\text { количе- } \\
\text { стве, \% }\end{array}$ \\
\hline $\begin{array}{l}\text { Для добычи угля (основные иностран- } \\
\text { ные поставщики - Германия, Польша, } \\
\text { Великобритания, США, Чехия, Китай, } \\
\text { Украина) }\end{array}$ & $27 / 4,2$ & 12,5 & $188 / 22,8$ & 87,5 \\
\hline $\begin{array}{l}\text { Для проходки и подготовки угледобычи } \\
\text { (Германия, Австрия, Великобритания, } \\
\text { США, Австралия, Китай, Украина) }\end{array}$ & $208 / 2,9$ & 33,5 & $414 / 5,3$ & 66,5 \\
\hline $\begin{array}{l}\text { Транспортное оборудование угольных } \\
\text { шахт (Германия, Польша, Чехия, Укра- } \\
\text { ина, Словакия) }\end{array}$ & $104 / 0,5$ & 36,8 & $178 / 1,3$ & 63,2 \\
\hline $\begin{array}{l}\text { Оборудование шахтной вентиляции } \\
\text { и обеспечения безопасности труда } \\
\text { (Германия, США, Китай, Украина) }\end{array}$ & $274 / 1,1$ & 60,9 & $131 / 1,5$ & 39,1 \\
\hline Итого & $\mathbf{6 1 3} / \mathbf{8 , 7}$ & $\mathbf{4 0 , 2}$ & $\mathbf{9 1 1} / \mathbf{3 0 , 9}$ & $\mathbf{5 9 , 8}$ \\
\hline
\end{tabular}

Источник: данные текущего архива Администрации Кемеровской области за 2015 гг.

Вместе с тем до начала реформ машиностроение было технологическим лидером и одной из ведущих отраслей экономики Кузбасса, производившей в 1988-1992 гг. до 14\% ВРП. Функционируют крупные машиностроительные предприятия (ПАО «Анжеромаш», ООО ПО «Юрмаш», ПАО «Сибтензоприбор», ПАО «Электромашина-М», ООО «Кемеровохиммаш», НПО «Развитие» и др.), на долю которых приходится до $11 \%$ суммарной стоимости основных производственных фондов региона.

При этом в Кузбассе за весь период рыночных реформ не было сформировано стратегических программных документов, связывающих инвестиции в развитие и технологическую модернизацию обрабатывающих и сырьевых производств, финансовые ресурсы банков и инвестиционных компаний, привлечение прямых иностранных инвестиций. Вопросы импортозамещения не отражены и в Стратегии социально-экономического развития Кемеровской области до 2025 г. («Кузбасс-2025») ${ }^{5}$. В данном документе отсутствует связь роста уровня жизни в Кузбассе

${ }_{5}^{5}$ Стратегия социально-экономического развития Кемеровской области до 2025 г. URL: http://docs.cntd.ru/document/990308346 (дата обращения: 01.03.2017). 
с модернизацией и импортозамещением в базовых отраслях промышленности - через рост производительности, новые рабочие места в машиностроении, радиоэлектронике и приборостроении, химической отрасли.

Подавляющая часть иностранного капитала в экономике Кемеровской области не связана с трансфером технологий и сконцентрирована в добывающих отраслях. Иностранные инвестиции оторваны от инновационного развития и технологической модернизации как производства сырья, так и его глубокой переработки в регионе.

Наибольшая часть иностранного капитала вложена в угольную и химическую отрасли региона (6,4 и 1,5\% соответственно, данные текущего архива Администрации Кемеровской области за 2015 г.), что способствует расширению технологически устаревших производств. Государство же не является значимым собственником в сырьевых $(0,8 \%)$ и обрабатывающих $(1,3 \%)$ отраслях экономики Кузбасса и не может ощутимо влиять на их технологическое, научно-производственное и социальное развитие.

О насущной потребности в импортозамещении для экономики Кемеровской области свидетельствуют значительный износ используемых отечественных средств производства и преобладание импорта в наименее изношенной его части. Так, износ крупного оборудования угольных разрезов (экскаваторов, буровых станков, насосных, трансформаторных станций) превысил 70\%, тогда как большая часть оборудования, закупленного за последние 10 лет и имеющего уровень износа менее $30 \%$, - импортное.

Между тем в Кузбассе существует задел для формирования институтов, поддерживающих неоиндустриальное импортозамещение, в частности, создан Координационный центр по развитию импортозамещения, имеются Региональный план и перечень инвестиционных проектов в сфере импортозамещения. Большая часть из них (всего на конец 2016 г. - 22 проекта) связана с выпуском сельскохозяйственной продукции (10 проектов, 17 млрд руб. инвестиций). При этом общая сумма запланированных инвестиций по проектам импортозамещения в Кузбассе (27,5 млрд руб. за 2016-2020 гг.) меньше, чем объем импорта угольными предприятиями современных машин и оборудова- ния - 30,9 млрд руб. (данные текущего архива Администрации Кемеровской области за 2015-2016 гг.).

Таким образом, можно сделать однозначный вывод о том, что неоиндустриальное импортозамещение в Кемеровской области тормозится из-за разрыва научно-производственных связей, слабой государственной поддержки, недостатка инвестиций у инновационно-ориентированных отраслей (машино-, приборостроение, выпуск современных синтетических материалов и сплавов). При этом проблемы нехватки инвестиций и барьеры на пути трансфера инноваций в региональное машиностроение возрастают на фоне роста добычи угля в Кузбассе, увеличения спроса на новые средства производства и автоматизации, удовлетворяемого за счет импорта. Что, однако, не снимает остроту проблемы высокого уровня их износа.

Следовательно, перспективы неоиндустриального импортозамещения в Кузбассе связаны с развитием выпуска машиностроительной продукции для замены наиболее изношенной части оборудования угольных предприятий. Рост спроса на современное горное оборудование может послужить восстановлению регионального машиностроительного комплекса только в том случае, если подавляющая часть звеньев цепи разработки и производства будет сконцентрирована в самом регионе. Это позволит реализовать главное стратегические преимущество региональных машиностроителей - возможность гибкой адаптации продукции к требованиям заказчиков, как на этапе проектирования и предсерийных испытаний, так и серийного производства. А это особенно важно для сложных горно-геологических условий угледобычи в Кузбассе.

Связующим звеном и первым шагом на пути развития импортозамещения в машиностроительном комплексе может стать формирование «пула региональных покупателей» оборудования, выпускаемого кузбасскими машиностроителями. Он представляет собой систему долгосрочных контрактов машиностроителей, угледобывающих и перерабатывающих компаний на совместное инвестирование разработки современных моделей горного оборудования, проведение их предсерийных испытаний и запуск серийного производства. Стимулировать заключение таких контрактов могут промышленные субсидии, предусмотренные ст. 10. закона «О промышленной политике 
в Российской Федерации» ${ }^{6}$, а также гарантии региональных властей.

Формирование «пула региональных покупателей» будет способствовать повышению конкурентоспособности машиностроительной продукции до мирового уровня, поскольку создаст условия для финансирования полного цикла разработки и внедрения инноваций в производство.

Для того чтобы частные и акционерные машиностроительные предприятия региона смогли успешно производить конкурентоспособную продукцию, необходима кластеризация как предложения, так и спроса на машины и оборудование для горной промышленности. Для этого должны быть решены следующие задачи.

1. Коренная реконструкция, техническая и технологическая модернизация машиностроительных предприятий Кузбасса, значительная часть которых была создана в 1960-1970-х гг. и имеет средний уровень износа основного капитала около $70 \%$.

2. Формирование инвестициионной программы инновациионого развития регионального машиностроения, отражающей потребности угольной, химической, металлургической отраслей Кузбасса в новом оборудовании.

3. Повышение степени кооперации машиностроительных предприятий региона, доля которой сегодня оценивается в пределах менее одной десятой. Фактически это означает, что комплектующие для продукции кузбасских машиностроительных предприятий, производимые в самой Кемеровской области, не покрывают и десятой доли ее стоимости. Преодоление технологической разобщенности региональных машиностроителей особенно важно для оборудования и производственных систем с заранее заданными свойствами и продукции адресного назначения, конкурентоспособной на региональном рынке. Значимой предпосылкой для развития кооперативных связей внутри кластера является наличие в регионе некоммерческого объединения «Ассоциация машиностроителей Кузбасса», включающего около тридцати предприятий Кемеровской, Новосибирской и Томской областей.

Для формирования неоиндустриально-импортозамещающего машиностроительного кластера в Кузбассе мы полагаем

\footnotetext{
${ }^{6}$ Федеральный закон от 31.12.2014 г. № 488-Ф3 «О промышленной политике в Российской Федерации» (с изм. и доп.). Система ГАРАНT. URL: http://base.garant.ru/70833138/ (дата обращения: 01.03.2017).
}

необходимым сконцентрировать усилия ассоциации и региональной администрации на следующих проблемных зонах.

Во-первых, формирование стратегии развития данного кластера, связывающей инвестиции в техническое перевооружение предприятий угольной, химической и машиностроительной отраслей, приборостроения, государственную поддержку и гарантии привлечения заемного финансирования.

Bo-вторых, расширение состава резидентов кластера, в который должны войти как машиностроительные предприятия, так и субъекты финансовой и научно-исследовательской, образовательной сфер региона, а также зарубежные разработчики современных машиностроительных технологий, программного обеспечения.

$B$-третьих, институциональное обеспечение:

- организация инвестиционного консорциума, в состав которого должны войти основные потребители машиностроительной продукции - предприятия угольной, химической, энергетической отраслей, формирующие на паритетных основах пул капиталовложений в региональное машиностроение;

- создание регионального агентства по привлечению и защите инвестиций в импортозамещение промышленной продукции;

- формирование гарантийного фонда инвестиций в машиностроение, главную роль в котором должна играть региональная администрация.

$B$-четвертых, формирование комплекса льгот по региональным налогам, предоставляемых резидентам импортозамещающего машиностроительного кластера.

Становление неоиндустриально-импортозамещающего машиностроительного кластера требует целенаправленного формирования комплекса связей между субъектами региональной экономики.

1 . В системе связей $b 2 b$ : создание представительств технологической платформы неоиндустриального импортозамещения на крупных предприятиях региона и в Кузбасском технопарке; формирование регионально-отраслевого венчурного фонда для финансирования разработки и испытаний нового оборудования, материалов и технологий, а также их продвижения на внутреннем рынке; привлечение банковского финансирования малых инновационных предприятий при университетах и НИИ путем заключения с машиностроительными предприятиями долгосрочных контрактов на внедрение результатов НИОКР; брендирование продукции регионального машиностроения и создание банка передовых разработок в отрасли. Для этого потребуются стартовые 
вложения в капитал регионально-отраслевого венчурного фонда в размере не менее 1 млрд руб., что эквивалентно годовому объему инвестиций в региональном отраслевом комплексе (2015 г.). Привлечение таких объемов капитала возможно за счет выпуска акций, держателями которых выступят, наряду с региональной администрацией, угольные компании - покупатели оборудования. При этом инвестиционная привлекательность покупки данных акций может быть обеспечена гарантиями их минимального курса и дивидендов.

Результатом формирования такого венчурного фонда может стать устойчивое предложение финансирования инновационных проектов малых инновационных предприятий при университетах и НИИ, резидентов Кузбасского технопарка, одобренных машиностроительными предприятиями и согласованных с угольными компаниями - покупателями оборудования. Сегодня объемы венчурных инвестиций в регионе не превышают 100 млн руб., поэтому их рост вызовет активизацию инновационной деятельности в машиностроении, при условии объединения усилий региональной администрации и угольных компаний по поддержке спроса на его продукцию.

2 . В системе связей $b 2 g$ : развитие новых форм государственно-частного партнерства в сфере импортозамещения продукции машиностроения: долгосрочные «контракты жизненного иикла инновации», связывающие государство и частных производителей соглашениями на разработку и выпуск субститутов импортного оборудования - от проектирования и подготовки кадров до продвижения новых отечественных брендов на рынке; «проектномодернизационное партнерство», когда государство выступит «задельным» инвестором, передавая предприятию объекты промышленной недвижимости, интеллектуальной собственности, повышая своими гарантиями его инвестиционную привлекательность для выхода на фондовый рынок; «внедренческое партнерство», в котором государство инвестирует в приобретение патентов, лицензий, новейшего оборудования, закупаемых за рубежом, с целью развития производств продукции, не имеющей аналогов в России.

Опыт производства адаптированного к требованиям заказчиков, а следовательно, наиболее конкурентоспособного (горнотранспортного, для проходки горных выработок и подземной добычи угля) оборудования, импорт которого, по прогнозам, за 2018-2020 гг. составит 6,5 млрд руб., имеют региональные предприятия - ПАО «Анжеромаш», ООО ПО «Юрмаш», финансово-экономическое положение которых сегодня нельзя признать удовлетворительным. Но при условии формирования технологической платформы неоиндустриального импортозамещения и развития долгосрочных инвестиционных контрактов переход к выпуску современной и конкурентоспособной техники, адаптированной под требования заказчиков и с налаженным сервисом, вполне возможен. Для аккумулирования капитала государственно-частного партнерства целесообразно использовать, наряду с бюджетными капиталовложениями, эмиссию целевых субфедеральных облигаций с налоговым приоритетом, привлекательных для угледобывающих компаний региона.

Конечным результатом развития государственно-частного партнерства в кузбасском машиностроении видится восстановление его доли в ВРП с сегодняшних 6\% до уровня начала $2000-х$ гг. $-13 \%$. В результате воссоздания отраслевого научноисследовательского сектора на базе технологической платформы неоиндустриального импортозамещения можно, на наш взгляд, получить $1 \%$ от ВРП, утраченный из-за ликвидации в годы рыночных реформ целого комплекса НИИ и КБ, обслуживавших угольную отрасль Кузбасса. Еще 1\% ВРП способна принести коммерциализация инновационных разработок технологической платформы в виде продажи патентов и лицензий на производство новых агрегатов горных машин, методов неразрушающего контроля и ремонта.

3. Для связей $b 2 s$ : потребуется создание Центра импортозамещающих технологий, который возьмет на себя патентную защиту, проектирование нового оборудования, экономическую экспертизу запуска его производства. Региональное машиностроение нуждается в банке данных идей, ноу-хау и других объектов интеллектуальной собственности, защищенных патентами или требующих такой защиты. Но сегодня деятельность научных коллективов университетов и НИИ плохо связана с бизнес-проектированием машиностроительных предприятий и угледобывающих компаний, поэтому необходимо ускорение обмена научно-технической информацией, в частности, путем создания при данном центре банка свободного доступа к патентованным технологиям и образцам техники. 
В целом с учетом предложенных мер воссоздание в регионе на новой технологической основе конкурентоспособного машиностроения, ориентированного, прежде всего, на угольную отрасль Кузбасса, позволит сгенерировать дополнительно 9\% ВРП и создать более 50 тыс. рабочих мест в обрабатывающем секторе.

Таким образом, откладывание системных мер в сфере неоиндустриального импортозамещения грозит потерей технологической идентичности и «сваливанием» российской экономики в длительную рецессию, которая еще больше закрепит технологическую отсталость. И лишь ускоренное инновационное развитие сырьевого комплекса с воссозданием на новой технологической основе выпуска конкурентоспособных средств производства, стимулирование спроса на них со стороны отечественной промышленности способны предотвратить окончательную деиндустриализацию российской экономики в сегодняшних непростых условиях. Исчерпание возможностей роста за счет экспорта сырья очевидно на примере моносырьевых регионов, таких как Кузбасс, причем главная проблема здесь связана не с ухудшением конъюнктуры мирового рынка, а с технологической примитивизацией и растущей импортозависимостью обрабатывающих отраслей.

\section{Литература}

Глазьев С. «Стратегия 2020»- антимодернизационный документ // Российский экономический журнал. 2012. № 2. С. 3-9.

Голофастова Н.Н., Михайлов В.Г., Середюк И. В. Трансформация экологоэкономической системы угледобывающего региона // Экономика и управление инновациями. 2017. № 1. С. 66-75.

Грозовский Б. Игра с нулевой суммой: почему у программы Трампа мало шансов на успех // РБК. 2017. 24 янв. URL: http://www.rbc.ru/opinions/economi cs/24/01/2017/588755289a7947d42845332e (дата обращения: 01.03.2017).

Жернов Е.Е. Экологические и социальные аспекты концепции неоиндустрализации в горнодобывающем регионе // Экономика и управление инновациями. 2017. № 2. C. 11-23.

Линдерт П.Х. Экономика мирохозяйственных связей. М.: Прогресс, 1992. $518 \mathrm{c}$.

Полтерович В. М. Институциональные ловушки и экономические реформы. М.: Российская экономическая школа, 1998. 42 с.

Пребиш Р. Периферийный капитализм: есть ли ему альтернатива? М.: ИЛА, 1992. 337 с.

Сакс Дж. Декарбонизация всей страны: смогут ли экономики G7 отказаться от нефти // РБК. 2015. 11 июн. URL: http://www.rbc.ru/opinions/economics/11/06 /2015/557985dd9a79478be86ecb18 (дата обращения: 01.03.2017).
Сидорович В. Безуглеродная Сибирь // Ведомости. 2016. 18 мая. URL: https://www.vedomosti.ru/opinion/articles/2016/05/18/641410-bezuglerodnaya-sibir (дата обращения: 01.03.2017).

Статья поступила 15.01.2018.

\section{Summary}

Zhironkin S.A., Gasanov M.A., Kolotov K.A., National Research Tomsk Polytechnic University, Tomsk

Neoindustrial Import Substitution: Utopia or Non-Alternative Way for Russia?

The article substantiates the need for Russian economy to enter the neo-industrial development path, the driver of which should be the import substitution. Its typology is examined and the role of the Government in ensuring the exit from institutional traps of neo-industrial import substitution is shown. On the example of the analysis of the basic industries import dependence problem in industrial region (Kemerovo region), recommendations are given for development of machine building as an industry whose import substitution can speed up Russian economy competitive manufacturing sector's reconstruction on a new technological basis, relying on the potential of the mining complex.

Neo-industrialization; deindustrialization; import dependence; import substitution; engineering; Kuzbass

\section{References}

Glaz'ev S. (2012) «Strategy-2020»-Anti-Modernization document. Rossijskij jekonomicheskij zhurnal [Russian Economic Journal]. Vol. 2. Pp. 3-9. (In Russ.)

Golofastova N.N., Mihajlov V.G., Seredjuk I. V. (2017) Transformacija jekologojekonomicheskoj sistemy ugledobyvajushhego regiona. [Jekonomika i upravlenie innovacijami [Economics and innovation management]. Vol. 1. Pp. 66-75. (In Russ.)

Grozovskij B. Igra s nulevoj summoj: pochemu u programmy Trampa malo shansov na uspeh. Available at: http://www.rbc.ru/opinions/economics/24/01/2017/58 8755289a7947d42845332e (accessed: 01.03.2017). (In Russ.)

Zhernov E.E. (2017) Jekologicheskie i social'nye aspekty koncepcii neoindustralizacii v gornodobyvajushhem regione. Jekonomika i upravlenie innovacijami [Economics and innovation management]. Vol. 2. Pp.11-23. (In Russ.)

Lindert P.H. (1992) Jekonomika mirohozjajstvennyh svjazej. Moscow, Progress Publ. 518 p. (In Russ.)

Polterovich V.M. (1998) Institucional'nye lovushki i jekonomicheskie re-formy. Moscow, Rossijskaja jekonomicheskaja shkola Publ. 42 p. (In Russ.)

Prebish R. (1992) Periferijnyj kapitalizm: est' li emu al'ternativa? Moscow, ILA Publ. 337 p. (In Russ.)

Saks D. Dekarbonizacija vsej strany: smogut li jekonomiki G7 ot-kazat'sja ot nefti. Available at: URL: http://www.rbc.ru/opinions/economics/11/06/2015/557985dd9a794 78be86ecb18 (accessed: 01.03.2017). (In Russ.)

Sidorovich V. Bezuglerodnaja Sibir'. Available at: https://www.vedomosti.ru/ opinion/articles/2016/05/18/641410-bezuglerodnaya-sibir (accessed: 01.03.2017) (In Russ.) 